\title{
MALTA BEFORE 870: SOME LIBYAN CONNECTIONS
}

\section{Anthony Luttrell}

In Roman times Malta was linked to Africa in various ways. The island lay on routes from Sicily to Libya, that is to Tripolitania and Cyrenaica, but it was too far to the east of the axis between Sicily and Carthage to have a major strategic importance. In fact Malta came into the Punic sphere only when Carthage became interested in Libya, and the Romans, like the Tunisian Muslims centuries later, were remarkably slow to conquer the island.' Even after the Roman conquest, many of Malta's contacts were with the Punic world of Carthage which lay to the west, ${ }^{2}$ and following 870 Malta was again dominated from Tunisia, whose Aghlabid rulers had conquered the island; possibly there were Tunisian influences not only in speech and religion but also in matters such as water supplies and housing. ${ }^{3}$ Even before the Muslim conquest of 870 there may have been contacts with Tunisia. The Byzantine general Belisarius touched or passed by Malta on his way from Kaukana in Southern Sicily to Carthage in $553 .{ }^{4}$ During the fifth century Malta was probably incorporated into the African Church which apparently held properties on Malta as late as 592. ${ }^{5}$ A passage in Procopius suggests that a number of Africans may

1. As emphasized in F. Rizzo, "Malta e Sicilia in Età romana: Aspelti di Storia politica e costituzionale," Kokalos, xxii-xxiii tomo I (1976-1977); similar points concerning the medieval period are made by A. Luttrell, "Approaches 10 Medieval Malta," in Medieval Malta: Malta before the Knights, ed. A. Luttrell (London, 1975), 17-18, 42. Rizzo's article constitutes a contribution to Maltese historiography which should provoke considerable debate. Pace Rizzo, 178, however, Pliny's insulae ad Africam versae seems to mean merely that Malta lay south rather than north of Sicily, as noted in A. Bonanno, "Malta in the Third Century," in The Roman West in the Third Century: Contributions from Archeology and History, ed. A. King - M. Henig, ii (Oxford, 1981), 505.

2. In addition to Rizzo, see Luttrell, 25, for references to a Punic inscription of ca. $100 \mathrm{AD}$ and other evidence; in due course the pottery and other finds may provide a fuller picture.

3. Hal Milleri: a Maltese Casale, its Churches and Paintings, ed. A. Luttrell (Malia, 1976), 27-31, 34-35.

4. Procopius of Caesaria, History of the Wars, ed. H. Dewing, ii (London, 1953), 130; cf. T. Brown, "Byzantine Malta: a Discussion of the Sources," in Medieval Malta, 73.

5. Brown, $72-73,75$. 
have fled to Malta in 544 as a result of Berber devastations at Susa; Procopius said that some "Libyans", who clearly came from Tunisia, "fled to Sicily and the other islands," but he did not actually mention Malta nor did he say whether the exile was permanent. 6 Subsequently, during the centuries before 870, Malta was certainly in Byzantine hands but its history in that period is very scantily documented. A traditional response to this difficulty has been to transfer to Malta various presumptions concerning the situation in Sicily, while there has also been a tendency to invoke Oriental or North African immigrations and influences in order to explain certain liturgical and linguistic features found, centuries later, on Malta.

Given the scarcity of information about Malta, deductions from Libyan parallels must be very largely hypothetical. The only known major Maltese monument of the period is the basilica church excavated at Tas-Silg and said to be datable only to the late-fourth or early-fifth century. Given the disturbances in the stratifications and pending the problematical publication of a final excavation report, it appears that this date turns on the rectangular baptistry basin built in the prehistoric temple outside the basilica church and on the altar of a type with a single leg or support. Other evidence of continued building activities - the presbitery or schola cantorum, the columns with crosses and the sixth-century tarsia work which was very probably imported - are all considered to point to a later period of splendour and perhaps to a fifth century or, more probably, a sixth or seventh century monastery, but they cannot provide an earlier date, especially in view of the fact that the plan of the basilica church was conditioned by that of the ancient temple into which it was built. ${ }^{8}$ There is no apparent reason why the baptismal font should be assigned with any confidence to the late-fourth century. ${ }^{9}$ Square basins cannot be dated so early in Sicily. ${ }^{10}$ In Cyrenaica basilica churches have seldom been

6. Procopius, ii. 414; cf. Brown, 73 et passim.

7. Cf. Luttrell, 23-25. For the earlier period, Maltese historiography looked to the Greek world: A. Bonanno, "The tradition of an Ancient Greek Colony in Malta," Hyphen (Malta), iv no. 1 (1983).

8. Missione Archeologica Italiana a Malta: Rapporto preliminare della Campagna 1963 (etc.), 8 vols. (Rome, 1964-1973), at 1965, 160-161; 1966, 118-119; 1967, 100-101. Cf. M. Cagiano de Azevedo, "Medieval Buildings Excavated at TasSilg and San Pawl Milqi in Malta," in Medieval Malta, 89.

9. M. Cagiano de Azevedo, in Missione 1966, 119, merely cites A.Khatchatrian, Les Baptistères paléochrétiens: Plans, Notices et Bibliographie (Paris, 1962), but this work gives very few, if any, square basins securely datable as early as the latefourth kentury.

10. This results from the systematic control of the references given in A. Messina, "Battisteri rupestri e Vasche battesimali nella Sicilia bizantina," Archivio Siorico Siracusano, n.s. i (1971). 
dated by excavation and almost none is datable before ca. 400." In Tripolitania there is one possible exception at Sabratha where the socalled Church III is dated, though only by the style of its mosaic, as probably being of the last quarter of the fourth century. To the south of this church is a room which formed part of an undated but earlier building and which contained a simple square baptismal basin set in a mosaic similar to and probably of the same date as that in the main church; this basin may be reasonably assigned to the same period presumed as the church. ${ }^{12}$ It seems furthermore that there is no evidence, for single-leg altars before the fifth century. ${ }^{13}$ The Tas-Silg plan with its presbitery is common in Libya and could date to the fifth century. At Siracusa and elsewhere in Sicily the transformation of pagan temples into churches such as occurred at Tas-Silg is not normally dated before the sixth century.14 The Tas-Silg basilica church appears most likely therefore to date to the sixth or possibly to the late-fifth century.

There is no positive evidence for any contacts between Libya and Byzantine Malta, though both to some extent shared arid and rocky conditions which might have encouraged comparable developments in rural housing. ${ }^{15}$ In late-Roman Libya there were extensive regions of frontier settlement with many small farm buildings and large central storehouses or estate centres known by the term gasr; the typical gasr was stone-built and defensible, but it was primarily agricultural rather than defensive in purpose. ${ }^{16}$ The Maltese islands were not part of a continental limes or frontier settlement zone and apparently had

11. S. Stucchi, Architentura Cirenaica (Rome, 1975), 360-364. This work contains a wealth of detail but tends to derive chronologies from stylistic considerations rather than from more cautiously topographical and stratigraphical approaches: critical reviews by D. White, in Art Bulletin, lix (1977), 623-626, and J. Ward Perkins, in American Journal of Archues)logy, lxxxiii(1979), 363-365.

12. P. Romanelli, "La Basilica cristiana nell'Africa Settentrionale Italiana," Atti del IV Congresso Internazionale di Archeologia Cristiana, i (Rome, 1940), 262; J. Ward Perkins - R. Goodchild, "The Christian Antiquities of Tripolitania," Archaeologia, xcv (1953), 15-17 and Plates VIllb, XXVII.

13. Reallexikon für Antike und Christentum, i (Stuttgart, 1950), 336-338.

14. References collected in A. Guillou, "La Sicile byzantine: État de Recherches," Byzantinische Forschungen, v (1977), 135-138.

15. Stucchi, 502-503 et passim.

16. The pioneer work of R.G. Goodchild and the views of Stucchi must be revised: B. Jones - G. Barker, "Libyan Valleys Survey," Libyan Studies, xi (1979/80); G. Barker - G. Jones, "The UNESCO Libyan Valleys Survey 1980," ibid., xii (1980/81); G. Barker - B. Jones, "UNESCO Libyan Valleys Survey 1979-1981: Palaeoecology and Environmental Archaeology in the Pre-Desert," ibid., xiii (1982). For a Roman wall and its rectangular towers, see O. Brogan, "Hadd Hajar, a clausura in the Tripolitanian Gebal Garian south of Asabaa," ibid., xi $(1979 / 80)$. 
no large farmhouses similar to the gasr. The round tower at Ta' Gawhar was apparently being used as a farmstead when it was destroyed towards the end of the third century AD. ${ }^{17}$ There were a number of these round towers on Malta which were probably built in the third century $\mathrm{BC}$ and may well have been used again for defensive purposes in the third century AD. ${ }^{18}$ They could have formed part of a warning system built on high inland sites and designed to send signals around the Maltese islands; ${ }^{19}$ there were small round towers in Southern Tunisia which were normally placed on high ground, probably as signal stations. ${ }^{20}$ In Malta and Gozo many ordinary people outside the main towns may have lived in caves ${ }^{21}$ or in rural houses of the non-military Byzantine type such as those excavated at Kaukana on the south coast of Sicily facing Malta. ${ }^{22}$

One general characteristic of the period may have been a slow but

17. (D. Trump), in Report on the Working of the Museum Department for the Year 1960 (Malta, 1962), 6-7; Figs.4-5. Plates I-IV.

18. Missione 1963, 21-22; Luttrell, in Medieval Malta, 21 n. 130; Bonanno (1981), 509. The towers at Tal-Baqqari and $\mathrm{Ta}$ ' Cieda present remarkable indications of continuity: M. Buhagiar - D. De Lucca - A. Luttrell, "The Tal-Baqqari Churches," in Hal Millieri, and A. Luttrell, "The Cappella of Birkirkara: 1402," Melita Historica, viii no. 2(1981), 157 n. 6. D. Trump, Malta: an Archaeological Guide (London, 1972), 89, seems to contradict his own report of 1960 in dating the tower at Ta' Gawhar to the third century AD.

19. Cf. P. Pattenden, "The Byzantine Early Warning System," Byz:ntion, liii (1983).

20. P. Trousset, Recherches sur le Limes Tripolitanus du Chott el-Djerid à la Frontière tuniso-libyenne (Paris, 1974), 65, 141-142; cf. D. Pringle, The Defence of Byzantine Africa from Justinian to the Arab Conquest (Oxford, 1981). See also E. Fentress, Numidia and the Roman Army: Social, Military and Economic Aspects of the Frontier Zone (Oxford, 1979), 90-91 et passim, for a few round towers and signalling with mirrors.

21. A. Luttrell, "Malta Troglodytica: Ghar-il-Kbir," Heritage (Malta), no. 24 (1979); M. Buhagiar, "Medieval Cave-Dwellings and Rock-Cut Churches in Malta," Atrium (Malta), no. 3 ((1983?)). Possible North African influences in Maltese catacombs are discussed in M. Buhagiar, Late Roman and Byzantine Catacombs and Related Burial Places in the Maltese Islands (M. Phil. thesis: London, 1982), which awaits publication.

22. References in Guillou (1977), 112-115; plan of Kaukana in Pelagatti, "Scavi e Ricerche archeologiche nella Provincia di Ragusa: 1961-1966," Archivio Storico Siracusano, xii (1966), 26; colour photograph in V. von Falkenhausen, "I Bizantini in Italia," in G. Cavallo et al., I Bizantini in Italia (Milan, 1982), plate 15. Cf. G. Tchalenko, Villages antiques de la Syria du Nord: le Massif du Bélus à l'Époque romaine, 3 vols. (Paris, 1953-1958); T. Kirilova Kirova, "Il Problema della Casa bizantina," Felix Ravenna, 4 ser., ii (1971); A Guillou, "L'Habitat nell'Italia bizantina: Esarcato, Sicilia, Catepanato (VI-XI secolo)," in Atti del Colloquio Internazionale di Archeologia Medievale, i (Palermo, 1976). 


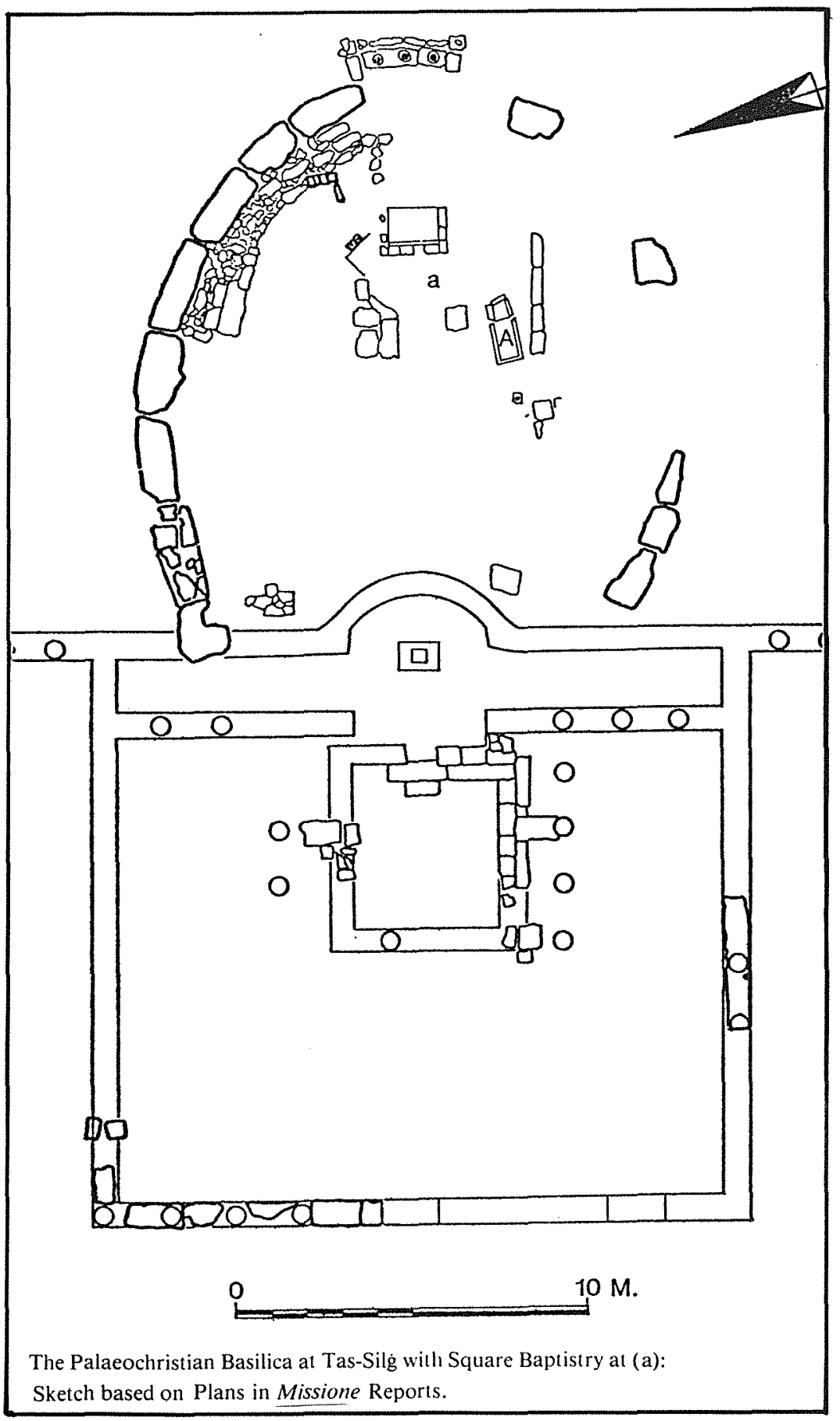


progressive warming up and drying up of the environment continuing at least to about $1000 \mathrm{AD}$. There is some evidence in North Africa and elsewhere for drought and the disappearance of the widespread olive culture. ${ }^{23}$ Such a process may in part account for the ruination of the very considerable and archaeologically well-attested olive production on Malta, ${ }^{24}$ though that subject really awaits a final elaboration of the finds from the "villa" at San Pawl Milqi as well as further excavations. In coastal Cyrenaica there is evidence also for major disasters including earthquakes, "barbarian" invasions and a catastrophic drought which is documented especially between 591 and 640 and which provoked an exodus of the comparatively dense Cyrenaican populace. ${ }^{25}$ This flight occurred just before the earliest Arab incursions into Cyrenaica in 642 and 645 . Some part of the Christian population remained on the coast at Barqa, which later served as bridgehead for a Byzantine attempt to hold the country against the Arabs with forces sent from Sicily in 688/9. The destruction of many Christian churches apparently came around 720 , though Coptic and other Christians seem to have survived for many centuries; ${ }^{26}$ at some uncertain date there was a systematic destruction of Christian churches in Cyrenaica, ${ }^{27}$ as apparently there was after 870 in Malta as well. ${ }^{28}$ Emigrations from Cyrenaica could have provided Malta with Oriental immigrants, ${ }^{29}$ while the reoccupation of Barqa might suggest that Malta, which lay on the sea-route from Sicily to Libya, may have had some special strategic value in the seventh century. ${ }^{30}$ The Maltese

23. Note various reservations advanced in B. Shaw, "Climate, Enviromment and History: the case of Roman North Africa," in Climate and History: Studies in Past Climates and their Impact on Man, ed. T. Wigley et al. (Cambridge, 1981).

24. A. Bonanno, "L'Habitat maltese in Età romana," Kokalos, xxii-xxiii tomo 1 (1976-1977), and idem, "Distribution of Villas and Some Aspects of the Maltese Economy in the Roman Period," Journal of the Faculty of Arts: University of Malta, vi, no. 4(1977). See also R. Virzi Hägglund, "Ghar ta' Iburdan: un Insediamento troglodilico in Elà romana," Kokalos, xxii-xxiii lomo 1 (1976-1977).

25. Stucchi, 357, 547-548. Stucchi presents numerous examples of the systematic walling-up of doorways (Figs. 570-573) as evidence of an exodus, but this seemingly inexplicable blocking of doorways seems more likely to liave been the result of later squatting.

26. According to Stucchi, 553-555; see also the convenient summary by J. Pedley, "The History of the City," in Apollonia, the Port of Cyrene: Excavations by the University of Michigan, 1965-1967, ed. J. Humphrey (1 ripoli, (1975)), 20-24.

27. Pedley, 24.

28. Luttrell, 26-27; Brown, 83-84; see also A. Luttrell, "The Christianization of Malta", Malla Year Book 1977 (Malta, 1977), 420-421.

29. Cf. S. Hood, "Isles of Refuge in the Early Byzantine Period," Annual of the British School at Athens, Ixv (1970), which documents refugees through datable poltery finds.

30. Cf. Brown, 73-78. 
islands were firmly in Byzantine hands down to 870; immigrations and influences from Libya are possible, but they lack firm documentation and will probably continue to do so until scientific excavation and a further study of pottery are able to provide information which is more than that at present available. 